\title{
The Interplay of Competition and Cooperation in the Innovation Process Between Established Organizations and Startups
}

\author{
Maicon Scaravonatto Mail ${ }^{1}$, Jorge Renato Verschoore $^{1} \&$ Jefferson Marlon Monticelli $^{2}$ \\ ${ }^{1}$ Business and Management School, Unisinos University, Porto Alegre, Brazil \\ ${ }^{2}$ São Paulo Business Administration School, Fundação Getulio Vargas EAESP São Paulo, São Paulo, Brazil \\ Correspondence: Jorge Renato Verschoore, Business and Management School, Unisinos University, Porto Alegre, \\ Brazil.
}

Received: December 9, 2020

Accepted: February 12, 2021

Online Published: June 1, 2021

doi:10.5430/ijba.v12n4p16

URL: https://doi.org/10.5430/ijba.v12n4p16

\begin{abstract}
This study aims to analyze the dynamic process of coopetition between an established organization and startups to develop innovation. We conducted an exploratory, qualitative study, based on Grounded Theory. The Grounded Theory allows the development of a theory emerging from data that is simultaneously collected and analyzed, determining the categories to observe the core questions. It can be divided into two stages: initial coding (open and axial coding) and focused coding. In the open coding, are defined categories and subcategories that are reviewed in the axial coding to generate more precise explanations? Along with the focused coding, the data organized from initial coding is categorized for an analytical understanding of the phenomena. In the first stage, we conducted eight semi-structured interviews with a homogeneous sample. An interview guide addressing coopetition factors was developed. As a result, we developed a framework from the theoretical background. This framework was evaluated by three executives and professors with experience in coopetition between large corporations and startups. The snowball technique was used to recruit the participants. Our findings reveal that different factors - market increase, strategic alignment, and technological alignment - are associated. We observed that coopetition not only helps in developing new markets but also in understanding the user demands of these markets. Thus, coopetition is an accelerator of innovation, since it allows the identification of the resource complementarity and technological scale gains.
\end{abstract}

Keywords: coopetition, collaboration, inter-organizational relationships, startups, fintechs, new ventures, finance industry

\section{Introduction}

Inter-organizational relationships have been characterized by competitive and collaborative strategies. Until the mid-1980s, these relationships were analyzed based on competition that deals with individualistic behavior and opportunism (Williamson, 1985). In the second half of the 1980s, studies about cooperation have focused on the resource asymmetries and interdependence of organizations and networks (Powell, 1990). Nevertheless, the dichotomy between competition and cooperation is no more suitable to understand inter-organizational relationships. In recent times, organizations engage in a continuous interplay of competition and cooperation recurrently called coopetition (Hoffmann, Lavie, Reuer, \& Shipilov, 2018). Coopetition is defined as "a paradoxical relationship between two or more actors simultaneously involved in cooperative and competitive interactions, regardless of whether their relationship is horizontal or vertical" (Bengtsson \& Kock, 2014, p. 182).

Since the rise of innovation ecosystems, a new form of coopetition has grown rapidly, encompassing incumbent organizations and insurgent startups (Hannah \& Eisenhardt, 2018). Usually, startups are considered agents of disruption that compete for the market share of established organizations (Blank, 2013). At the same time, some established organizations also consider startups as potential collaborators for improving their value proposition (Weiblen \& Chesbrough, 2015). Nonetheless, the results of coopetition between large organizations and startups have not been conclusive. On the one hand, Hora, Gast, Kailer, Rey-Marti, \& Mas-Tur (2018) found that startups coopete with large organizations to increase their sales, growth, and opportunities while large organizations seek new technologies and innovation capabilities. On the other hand, Ejsmont (2017) has not found significant results about coopetition between large organizations and startups mainly regarding innovation, profitability, and number of customers. 
Coopetition research field still in its infancy. It has a fragmented and limited body of literature (Ritala, Kraus, \& Bouncken, 2016). In these terms, there are research avenues to explore. Some scholars highlight the gaps in the understanding of coopetitive innovation practices and structures (Basterretxea, Charterina, \& Landeta, 2019). Other scholars pointed out that few studies have addressed service industries (McCarthy, Carleton, Krumpholz, \& Chow, M, 2018) mainly regarding startups (Ejsmont, 2017; Hora et al., 2018). More recently, scholars postulate that a critical issue concerning coopetitive strategy is to understand how the interplay of competition and cooperation take place (Minà, Dagnino, \& Vagnani, 2020). Based on these gaps, we ask the following research question: "How does the interplay of competition and cooperation between established organizations and startups take place?" Thus, our study aims to analyze the dynamic process of coopetition between an established organization and startups to develop innovation. We conducted an exploratory, qualitative study, based on Grounded Theory and conducted by the guidelines proposed by Glaser (1998) and Strauss and Corbin (1998).

We choose to study the Brazilian financial ecosystem, the largest financial ecosystem in Latin America (PwC, 2018) and with high potential for disruptive innovations. It has been affected by regulatory advances such as Open Banking, allowing financial technology startups (fintechs) to gain market share through the creation of new technological solutions. Fintechs are startups that adopt agile business models to compete with established financial organizations. Fintechs offer customized services to specific niches, based on data-driven solutions, innovative culture and flexible structure (Lee \& Shin, 2018). The number of Fintechs operating in Brazil grew by $28 \%$ between the years 2019 and 2020 (FintechLab, 2020).

Our paper contributes in different ways to literature about coopetition and innovation. First, this study follows the call for research on coopetition between start-ups and large organizations (Bouncken, Gast, Kraus, \& Bogers, 2015; Lechner, Dowling, \& Welpe, 2016), specifically about fintechs and banks (Fonseca \& Meneses, 2020) and seeks to develop knowledge on the main features of coopetition between start-ups and corporates (Hora et al., 2018). Second, our paper explains how large organizations and startups manage their coopetitive relationships, and what implications such relationships have in terms of benefits and risks (Hora et al., 2018). Third, we develop a theoretical framework, using grounded theory, to explain the interplay of competition and cooperation between large organizations and startups to develop innovation. Grounded theory is a non-usual method that allows explaining social phenomena from the constant comparison between emerging data and theory (Suddaby, 2006).

The paper starts by addressing the theoretical assumptions underlying the concept of coopetition in the context of large organizations and startups. It then describes methodological aspects, outlining the research approach, and providing details about the grounded theory method used. Later, while outlining the research framework, our paper presents quotes from representatives of established organizations and startups. Finally, the paper ends with conclusions, and a discussion of practical implications, suggestions for a new research agenda, and limitations.

\section{Theoretical Reference}

\subsection{Coopetition From Competitive and Cooperative Strategies}

Studies have discussed competition and cooperation as two separate and distinct issues (Nutter \& Noore, 1976). More recently, management studies have understood that interfirm rivalry includes not only competition between firms but also the interplay of competitive and cooperative strategies between rivals (Minà et al., 2020). Scholars have considered that firms usually "engage in competition and cooperation with each other" (Hoffmann et al., 2018, p. 3). Consequently, coopetition could be a balanced blend of competition and cooperation (Mattsson \& Tidström, 2015) that can be presented from the perspectives of the game theory, transaction cost theory, resource-based view and networks, mainly at the network and firm level (Czakon \& Rogalski, 2014). In this study, we used the game theory, resource-based view, and networks as a theoretical background to explain the interaction between large organizations and startups.

From the game theory perspective, researchers analyze coopetition as a win-win game, discussing the balance between value creation (aiming at common benefits) and value appropriation (aiming at private benefits). Thus, the participants act creating value to each other through a dynamic process of competition and cooperation (Brandenburger \& Nalebuff, 1996; Padula \& Dagnino, 2007). In this sense, coopetition, as a competitive game, is a behavior sustained by their deliberate self-interest, while cooperation promotes self-improvement based on that competitiveness. Strategies for managing the balance between competition and cooperation become crucial, as they determine how rival partners can compete and cooperate simultaneously (Peng, Yen, \& Bourne, 2018).

From the resource-based view, researchers have been used mainly to mobilize resources and technologies as resources that can become the basis for creating a competitive advantage (Lado, Boyd, \& Hanlon, 1997; Quintana-García \& 
Benavides-Velasco, 2004). Resources are cumulated, mobilized, and used to create a sustainable competitive advantage that allows resource accumulation (Lado, Boyd, \& Wright, 1992). Consequently, the firms search for partners that could have single technological resources (Barney, 1991). Thus, firms make decisions based on coopetition to increase their innovation capacity and technological performance (Della Corte, 2018; Granata, Lasch, Le Roy, \& Dana, 2018), regarding that network relationships can overcome the lack of resources (Crick \& Crick, 2020).

From the network's perspective, scholars have emphasized the relevance of characteristics and positions in networks, mainly in horizontal relationships. Networks are the basis to develop competitive advantage explaining how to access and extend knowledge and resources outside the firm through coopetitive relationships (Chen, Yao, Zan \& Carayannis, 2020; Rusko, 2014). In this sense, coopetition shows that the differential of the configurations are the structural positions between the firms and the way they will cooperate, with direct or indirect connections, according to the asymmetries of the members. Managing connections between relationships is considered a relationship portfolio. This portfolio is part of a strategic resource of a firm that comprises all relationships with other organizations that it owns (Wilkinson \& Young, 2002). However, it depends on the position that firm has in a network, developing a relevant role based on its degree centrality (Chiao, Lin \& Huang, 2020; de Carvalho, Cruz, de Carvalho, Duclós, \& Corrêa, 2020).

Coopetition can be used to analyze the interactions based on competition and cooperation among suppliers, customers, and competitors, considering the dynamics in this context to deal with uncertainties (Gnyawali \& Park, 2009). Cooperative actions permit enlarging the market size while competitive actions define how to divide the results obtained. Combining cooperation and competition bring advantages and risks that imply a paradoxical, multifaceted, and multilevel phenomenon (Raza-Ullah, Bengtsson, \& Kock, 2014; Wilhelm \& Sydow, 2018).

Coopetition factors such as market growth (prospecting for customers and perceiving vulnerabilities), strategic alignment (objective congruence), and technological alignment (technological capacity, resource complementarity, and asymmetry are drivers for assessing the likelihood of cooperation) (Gnyawali \& Park, 2009). Regarding resource similarity and market commonality (Shijaku \& Ritala, 2020), large organizations and startups deal with different challenges according to their firm size, exploiting advantages from coopetition.

\subsection{Coopetition Among Large Organizations and Startups}

Startups have been recognized by disruptive innovations because they bring new business models that simplify, become more efficient and less complex the process and the relationships with the customers. Consequently, startups are fast and agile, creating an advantage in markets that value the change speed to promote digital transformation and reach success (Salkowitz, 2013). Fintechs have been born in this digital transformation, but they must be part of an ecosystem to develop the business model through a business multilateral platform. An ecosystem is relevant because it provides a structure and rules in a market that proxy providers and customers, making possible that both exchange roles and create value to the platform (Van Alstyne, Parker, \& Choudary, 2016). In this model, the organizations can be suppliers, producers, competitors, and other interested parts in the ecosystem.

Regarding the parts evolved in an ecosystem, the coopetition can be divided into unintentional or emergent (there are several actors involved in the coopetition, and some of these actors have not noticed the coopetition) or intentional or deliberated (every actor is aware of their involvement with the coopetition) (Rusko, 2014). On the one hand, most of the existing studies consider coopetition as a deliberated and emergent strategy, which means that a deliberate strategy on the firm level may be influenced by emergent coopetition on other levels (Dahl, Kock, \& Lundgren-Henriksson, 2016; Tidström \& Rajala, 2016). On the other hand, coopetition can be considered an explicit strategy that considers the simultaneous and symmetric existence of competition and cooperation (Hoffmann et al., 2018), while the interplay of competition and cooperation may be explicit or implicit (Minà et al., 2020; Verschoore \& Adami, 2020).

Large organizations have established co-working with startups to revitalize their entrepreneurial orientation (Weiblen $\&$ Chesbrough, 2015) and improve decision making (Krommendijk, 2016). At the same time, startups have searched to overcome liabilities of youth, newness, and smallness as constrained resources and scale economies, developing coopetitive strategies with large organizations (Banerjee, Riquelme, \& Johari, 2016). Moreover, coopetition can be imposed by the customers or by a structural complementary agent as a regulatory authority (Nakanishi, 2020), mainly when there is a relationship between fintechs and large organizations that emphasizes asymmetric coopetition based on resources (Blanka \& Traunmüller, 2020; Gast, Gundolf, Harms, \& Collado, 2019).

Large organizations have resources, routines, and experience but lack a certain innovation capability. Startups often develop innovative ideas, are flexible and agile, and aspire to achieve fast and high growth, but they tend to lack the required resources and market access. Coopetition represents an opportunity for startups facing restrictions in 
resources, while large organizations benefit from startups' innovative potential (Weiblen \& Chesbrough, 2015). The management of coopetition includes the issues of how to choose the right partner, how to promote a good dynamic of coopetition, and which governance mechanisms to adopt. Startups' selection of the coopetitive partner is mainly driven by their aim to retain their independence, to share a common vision with the partner, and to build on an understanding of both partners' roles. For large organizations, the selection is mainly based on a fit between their culture and the startups' business models and knowledge (Blanka \& Traunmüller, 2020). Factors that promote a good organization of coopetition include a common mindset and vision, mutually developed objectives and milestones, trust and honesty, and well-organized communication channels through which information and knowledge can be exchanged frequently (Hora et al., 2017).

Specifically about the financial industry, it is dealing with a paradigm shift process with new consumer demands, customization of financial products and services, and the emergence of new technologies and new business models based on digital transformation (Fonseca \& Meneses, 2020). In this context, large organizations as banks cooperate with fintechs that are interested in the support in regulatory issues and market access, while fintechs cooperate with banks through customized solutions based on emergent technologies that allow making a digital transformation (Holotiuk, Klus, Lohwasser, \& Moormann, 2018) (Table 1).

Table 1. Subcategories of coopetition factors based on the theoretical foundation

\begin{tabular}{|c|c|c|c|}
\hline \multicolumn{4}{|c|}{ Coopetition factors } \\
\hline Factors & Categories & Concept & Reference \\
\hline \multirow[t]{2}{*}{$\begin{array}{l}\text { Market } \\
\text { increase }\end{array}$} & $\begin{array}{l}\text { Prospecting } \\
\text { strategy }\end{array}$ & $\begin{array}{l}\text { Firms with a prospecting strategy often look for } \\
\text { opportunities to improve their knowledge, } \\
\text { bargaining power, and global capabilities. Rival } \\
\text { partners benefit from investment sharing to } \\
\text { increase their chances of accessing new markets. } \\
\text { These are items used for them to become } \\
\text { successful, increasing their competitive strengths } \\
\text { against rivals. }\end{array}$ & $\begin{array}{l}\text { Gnyawali \& Park, } \\
2009 \text {; Nonaka, } \\
\text { Kodama, Hirose, } \\
\& \quad \text { Kohlbacher, } \\
\text { 2014; Peng et al., } \\
2018\end{array}$ \\
\hline & $\begin{array}{l}\text { Perceptible } \\
\text { vulnerability }\end{array}$ & $\begin{array}{l}\text { The greater the perceived vulnerability, the greater } \\
\text { the likelihood that firms will collaborate with } \\
\text { competitors to increase their ability to compete } \\
\text { against the strongest players. The effectiveness of } \\
\text { a network can be understood through trust and } \\
\text { relationships that are developed between } \\
\text { individuals. }\end{array}$ & $\begin{array}{l}\text { Ahuja, 2000; } \\
\text { Gnyawali \& Park, } \\
2009 ; \quad \text { Hitt, } \\
\text { Ireland, \& } \\
\text { Hoskissonm 2007; } \\
\text { Lacam \& Salvetat, } \\
\text { 2017; Nonaka et } \\
\text { al., 2014 }\end{array}$ \\
\hline $\begin{array}{l}\text { Strategic } \\
\text { Alignment }\end{array}$ & $\begin{array}{l}\text { Objectives } \\
\text { Congruence }\end{array}$ & $\begin{array}{l}\text { The partners' strategic goals converge while their } \\
\text { competitive goals diverge. Balance between } \\
\text { competition and cooperation become crucial, as } \\
\text { they determine the way in which rival partners can } \\
\text { compete and cooperate simultaneously. These } \\
\text { results help to analyze the impact of individual } \\
\text { companies' coopetition strategies from a } \\
\text { systematic perspective and differentiate the } \\
\text { creation and capture of value. }\end{array}$ & $\begin{array}{l}\text { Gnyawali \& Park, } \\
\text { 2009; Hamel, } \\
\text { Doz, \& Prahalad, } \\
\text { 1989; Peng et al., } \\
\text { 2018 }\end{array}$ \\
\hline $\begin{array}{l}\text { Technological } \\
\text { Alignment }\end{array}$ & $\begin{array}{l}\text { Technological } \\
\text { capacity }\end{array}$ & $\begin{array}{l}\text { Technological capacities indicate that the unique } \\
\text { skills of the potential partner, such as innovative } \\
\text { technology and experience in a given field, are } \\
\text { very important factors when selecting partners. In } \\
\text { addition, Resource-Based View states that firms } \\
\text { are looking for partners who have unique } \\
\text { technological resources. Firms participate in } \\
\text { Coopetition to increase their capacity for }\end{array}$ & $\begin{array}{lr}\text { Barney, } & 1991 ; \\
\text { Emden, } \\
\text { Calantone, } \\
\text { Droge, } \\
\text { Granata et al., } \\
2018\end{array}$ \\
\hline
\end{tabular}


innovation and technological performance.

\begin{tabular}{|c|c|c|}
\hline $\begin{array}{l}\text { Resource } \\
\text { Complementarity }\end{array}$ & $\begin{array}{l}\text { Resource complementarity is crucial for } \\
\text { collaborative success, mainly because of synergies } \\
\text { and economies of technological scope. Firms must } \\
\text { apply a resource-based view to Coopetition and } \\
\text { defend the benefits of mutually developing and } \\
\text { leveraging technologies and resource } \\
\text { complementarity. }\end{array}$ & $\begin{array}{lr}\text { Barney, 2001; } \\
\text { Bengtsson } \quad \& \\
\text { Kock, 2014; } \\
\text { Bleeke \& Ernst, } \\
\text { 1991; Sarkar, } \\
\text { Echambadi, } \\
\text { Cavusgil, \& } \\
\text { Aulakh, 2001 }\end{array}$ \\
\hline $\begin{array}{l}\text { Resource } \\
\text { Similarity }\end{array}$ & $\begin{array}{l}\text { Resource similarity is essential for the search for } \\
\text { partners and subsequent organizational learning } \\
\text { and knowledge transfer, providing a common } \\
\text { ground necessary to realize the potential of } \\
\text { technology and to communicate with each other, } \\
\text { thereby increasing its efficiency. Cooperation } \\
\text { facilitates a co-learning process, thus increasing } \\
\text { the degree of similarity in the pattern of } \\
\text { competitive action between rival partners. }\end{array}$ & $\begin{array}{l}\text { Emden et al., } \\
\text { 2006; Gnyawali \& } \\
\text { Park, 2009; Peng } \\
\text { et al., 2018 }\end{array}$ \\
\hline
\end{tabular}

Source: Created by the author.

\section{Methodology}

In order to analyze the dynamic process of coopetition between an established organization and startups to develop innovation, an exploratory and qualitative study was conducted through Grounded Theory. The Grounded Theory allows developing a theory emerging from data that is simultaneously collected and analyzed, determining the categories to observe the core questions (Suddaby, 2006). It can be divided into two stages: initial coding (open and axial coding) and focused coding. Initial coding involves data examination and interpretation based on data, observers` interpretation, and the interaction with data and researcher to find similarities and differences. In the open coding are defined categories and subcategories that are reviewed in the axial coding to generate more precise explanations (Corbin \& Strauss, 2008). Along with the focused coding, the data organized from initial coding is categorized to allow an analytical understanding of phenomena (Charmaz, 2006). Thus, we used Grounded Theory to develop constructive and interpretative perspectives from empirical generalizations, in three different stages (Figure 1).

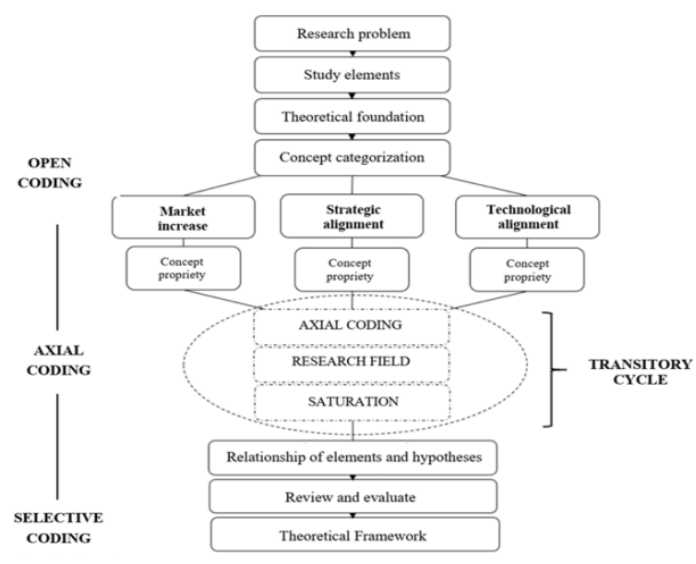

Figure 1. Research methodology 
In the first stage, we conducted eight semi-structured interviews. We used a homogeneous sample, that is, this sample evolved during the research according to the relevant concepts explored for the participants. It was developed an interview guide that addressed coopetition factors that, with the open coding, but it was necessary to make some settings after the pre-test to adjust some questions to factors identified. We attached reminders with our data and transcriptions, creating field notes. As result, we developed a framework from a theoretical background. This framework was evaluated by a jury with three executives and professors with experience in coopetition between large corporations and startups. The next step was to collect data through interviews in the first transitional cycle. The snowball technique was therefore used to recruit the participants. At the end of this stage, we noticed that did not reach the theoretical saturation and decided to advance in data collection, resulting in the second stage of the transitional cycle.

We described the data in codes and categories to answer the research question. We constantly compared the data, regarding the transcriptions and reminders, to rebuild the meaning of data. After I1 and I2, we noticed that the interviews were based on very comprehensive responses. We found similarities with the theoretical background, especially when dealing with the market increase factor. For the next two interviews (I3 and I4), the interviewees asked more specific questions, but the interviewees spoke freely. We obtained an adequate level of depth WHICH allowed us to identify new open codes. However, the strategic alignment factor was below expectations and we chose to include it as the first topic in the next interviews. When continuing the description of the data in codes and categories, we carried out the second stage of the transitional cycle with the interviews I5, I6, I7, and I8 and found more synergy through the experience of the interviewees in large organizations. Finally, I9 and I10 made it possible to advance the technological alignment factor and reinforced the continuous description of data in open codes. The interview cycles are described in Table 2.

Table 2. Stages of the transitional interview cycle

\begin{tabular}{|c|c|c|c|c|c|}
\hline \multicolumn{6}{|c|}{ First stage of the transitional interview cycle } \\
\hline Interviewee & Position & Organization & Work experience & Highest degree & $\begin{array}{l}\text { Interview } \\
\text { Duration }\end{array}$ \\
\hline I1 & $\begin{array}{l}\text { Director of Information } \\
\text { Technology }\end{array}$ & $\begin{array}{l}\text { Large } \\
\text { organization }\end{array}$ & 27 years & MBA & $34 \mathrm{~min}$ \\
\hline $\mathrm{I} 2$ & Founder and CEO & Fintech & $\begin{array}{l}2 \text { years ( }+13 \text { years as an } \\
\text { executive) }\end{array}$ & $\begin{array}{l}\text { Master's } \\
\text { Degree }\end{array}$ & $32 \min$ \\
\hline $\mathrm{I} 3$ & Founder and CEO & $\begin{array}{l}\text { Startup } \\
\text { (health-tech) }\end{array}$ & $\begin{array}{l}2 \text { years }(+18 \text { in the financial } \\
\text { ecosystem) }\end{array}$ & Ph.D. Degree & $41 \mathrm{~min}$ \\
\hline I4 & Professor & University & $\begin{array}{l}30 \text { years as a professor and } \\
\text { consultant in the area of } \\
\text { strategic management }\end{array}$ & Ph.D. Degree & $36 \min$ \\
\hline I5 & Operations Director & $\begin{array}{l}\text { Large } \\
\text { organization }\end{array}$ & 23 years & Specialization & $34 \mathrm{~min}$ \\
\hline I6 & Operations Director & $\begin{array}{l}\text { Large } \\
\text { organization }\end{array}$ & 10 years & Specialization & $37 \mathrm{~min}$ \\
\hline I7 & Operations Director & $\begin{array}{l}\text { Large } \\
\text { organization }\end{array}$ & 17 years & Specialization & $51 \mathrm{~min}$ \\
\hline I8 & Operations Director & $\begin{array}{l}\text { Large } \\
\text { organization }\end{array}$ & 31 years & Specialization & $34 \min$ \\
\hline \multicolumn{6}{|c|}{ Second stage of the transitional cycle } \\
\hline Interviewee & Position & Organization & Work experience & Highest degree & $\begin{array}{l}\text { Interview } \\
\text { Duration }\end{array}$ \\
\hline I9 & CEO & Fintech & $\begin{array}{l}3 \text { years }(+12 \text { years as an } \\
\text { executive in the financial } \\
\text { ecosystem) }\end{array}$ & MBA & $44 \mathrm{~min}$ \\
\hline $\mathrm{I} 10$ & $\begin{array}{l}\text { Superintendent of } \\
\text { Corporate Architecture }\end{array}$ & $\begin{array}{l}\text { Large } \\
\text { organization }\end{array}$ & $\begin{array}{l}10 \text { years as an executive in } \\
\text { the financial ecosystem }\end{array}$ & $\begin{array}{l}\text { Master's } \\
\text { Degree }\end{array}$ & $32 \mathrm{~min}$ \\
\hline
\end{tabular}


In the second stage, following the Grounded Theory, we analyzed and collect data concurrently. The data analysis followed the GT, being subdivided into open, axial, and focused coding. Open coding was used to develop codes for the categories. Axial coding was used to create an interconnection of categories and concepts. Focused coding was used for theory building. In that sense, it was necessary to make some settings in the questionnaire, again, in the second stage of the transitional cycle, resulting in some more focused questions. However, in the second stage of the transitional cycle, each collection was performed and analyzed individually until we reached the theory`s explanatory power approximately null and, consequently, to reach the theoretical saturation.

In the third stage, we realized the data analysis. We constantly compared data and theoretical background to reach theoretical saturation. Data from the last two interviews, I9 and I10, confirmed recurring patterns and did not add new categories or subcategories. With theoretical saturation, we classified the data into concepts and subcategories using axial coding. Finally, we refined this classification relating the subcategories with quotes from interviews.

We established the reliability criteria of GT to ensure the method applicability through an auditable track. According to Lincoln and Guba (1995), we observed four criteria to establish reliability (Table 3).

Table 3. Research reliability

\begin{tabular}{|c|c|c|}
\hline $\begin{array}{l}\text { Reliability } \\
\text { Criteria }\end{array}$ & GT Principles & Techniques Used in Research \\
\hline Credibility & $\begin{array}{l}\text { The credibility of a study is determined } \\
\text { when researchers or readers are } \\
\text { confronted with the experience, as they } \\
\text { can recognize it by gaining trust in the } \\
\text { truth of the results (Nowell, Norris, } \\
\text { White, \& Moules, 2017). }\end{array}$ & $\begin{array}{l}\text { - Open coding } \\
\text { - Axial coding } \\
\text { - Selective coding } \\
\text { - Constant Comparative Approach } \\
\text { - Researcher immersed in data }\end{array}$ \\
\hline Transferability & $\begin{array}{l}\text { Transferability is about the researcher } \\
\text { providing dense descriptions so that } \\
\text { those who aim to transfer the findings } \\
\text { for their interest, can judge them } \\
\text { (Nowell et al., 2017). }\end{array}$ & $\begin{array}{l}\text { - Theoretical sensitivity } \\
\text { - Generalization of research }\end{array}$ \\
\hline Confirmability & $\begin{array}{l}\text { Confirmability is related to the } \\
\text { establishment that the researcher's } \\
\text { interpretations and findings are derived } \\
\text { from the data, thus requiring the } \\
\text { researcher to demonstrate how } \\
\text { conclusions and interpretations were } \\
\text { reached (Nowell et al., 2017). }\end{array}$ & $\begin{array}{l}\text { - Theoretical saturation } \\
\text { o GT schematic process } \\
\text { o Definition of each phase of GT } \\
\text { o Definition of the transitional cycle } \\
\text { - Application of GT } \\
\text { o Theoretical Background } \\
\text { o Data collection } \\
\text { O Open coding } \\
\text { O Axial coding } \\
\text { Theoretical saturation } \\
\text { - Adaptation of theoretical sampling } \\
\text { o Selective coding }\end{array}$ \\
\hline Reliability & $\begin{array}{l}\text { Reliability is achieved when } \\
\text { researchers can guarantee logical, } \\
\text { traceable and documented processes } \\
\text { (Nowell et al., 2017). }\end{array}$ & $\begin{array}{l}\text { - Evidence } \\
\text { - Data Organization } \\
\text { - Reminders } \\
\text { - Description of data in codes and categories } \\
\text { - Classification of data into concepts and properties } \\
\text { - Adaptation of theoretical sampling }\end{array}$ \\
\hline
\end{tabular}




\section{Discussion}

In this section, we explained the data interpretation. We organized the subcategories around the concepts, integrating the identified factors and, consequently, refining the theory with the empirical evidence from interviews. Thus, in this stage, we created the database to obtain the representation and visualization of the data to develop a theoretical framework (Table 4).

We considered the three factors (strategic alignment, market increase, and technological alignment) to develop a theoretical framework to explain the interplay of competition and cooperation between large organizations and startups to develop innovation. In this sense, the substantive theory that emerged is presented in the theoretical framework (Figure 2), showing the coopetition factors and their relationships.

Our theoretical framework shows that there is a soon-to-be discovered probability to carry out the cooperation of large organizations and Fintechs. In the entry model of the theoretical framework, coopetition factors must be explored in large organizations as a result of their properties. In this case, for coopetition to occur, the factors of large organizations must be in synergy with the factors of fintechs. Our theoretical framework was developed with six properties that are divided into three groups of factors, which are: Market Increase, Strategic Alignment, and Technological Alignment.

In the first factor, the market increase factor, we evaluate the characteristics of the prospecting strategy and perceived vulnerability. Prospecting strategy consists of carefully analyzing and studying the opportunities offered by the market that is, always searching for the best way to be ahead. In this sense, coopetition can provide the best partners. If an organization can effectively learn through competitive ties, it can become a better partner and take advantage of the most attractive long-term opportunities (Gnyawali \& Park, 2009). Therefore, large organizations with a prospecting strategy often look for opportunities to improve their knowledge, bargaining power, and global capabilities so that they can become more successful, thus increasing their competitive strengths against their rivals.

On the market increase factor, a good strategy aims to reduce the company's uncertainties and risks in the market. At the same time, the vulnerability can be the result of external or internal sources. From the perspective of external sources, the dynamics of competitors, suppliers, customers, or other factors in the industry create a fundamental role in the search for opportunities. The greater the stock of resources in an organization, the greater its attractiveness to partners and, consequently, the ability to create new relationships and generate new opportunities due to its position in the network structure (Ahuja, 2000). From the perspective of internal sources, coopetition helps large organizations to focus on their core competencies as a source of their competitive advantages. However, the ability to create value for core competencies should never be considered acquired (Chiambaretto, Maurice, \& Willinger, 2020). Therefore, the greater the perceived vulnerability, the greater the likelihood that large organizations will cooperate with startups to increase their ability to compete against the strongest players.

In the second factor, the strategic alignment factor, the characteristics of objective congruence during coopetition were evaluated. In this case, the strategic objectives of the partner converge while their competitive objectives diverge, which is one of the conditions in which mutual gain is possible (Hamel et al., 1989). These results help to analyze the impact of coopetition strategies from a systematic perspective and to differentiate the creation and capture of value (Gnyawali \& Park, 2009). Therefore, the congruence of objectives presents the importance of mutual gain, especially when cooperation involves resources that have the potential to create and capture value.

Table 4. Axial coding

\begin{tabular}{|c|c|c|c|c|}
\hline Factors & Subcategories & Concept & Open coding & Quotes from interviews \\
\hline $\begin{array}{l}\text { Strategic } \\
\text { alignment } \\
\text { factor }\end{array}$ & $\begin{array}{l}\text { Purpose and } \\
\text { identity }\end{array}$ & $\begin{array}{l}\text { Transparency and } \\
\text { clarity within the } \\
\text { strategy. It is } \\
\text { necessary to know } \\
\text { what the demands are } \\
\text { and what the role of } \\
\text { each party is for a } \\
\text { unique identity within } \\
\text { the collaboration. }\end{array}$ & $\begin{array}{l}\text { Purpose alignment } \\
\text { Having common purposes } \\
\text { Increased identity } \\
\text { Transparency within the } \\
\text { strategy } \\
\text { Partnership of Disinterest }\end{array}$ & $\begin{array}{l}\text { "Strategic alignment } \\
\text { generates an increase in } \\
\text { identity to have positive } \\
\text { long-term impacts" (I1) } \\
\text { "The value proposal between } \\
\text { the parties must be clear" (I2) }\end{array}$ \\
\hline
\end{tabular}




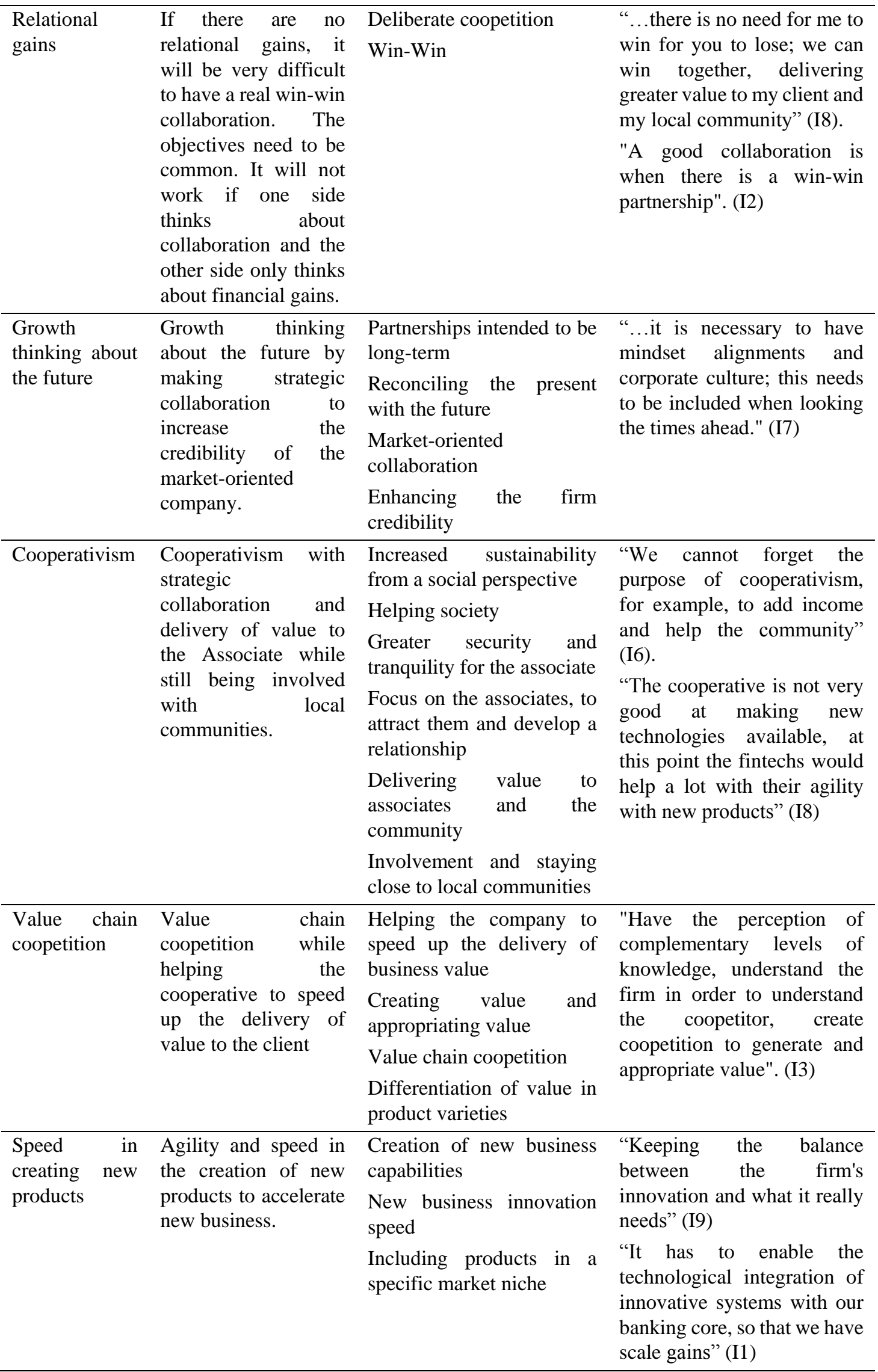




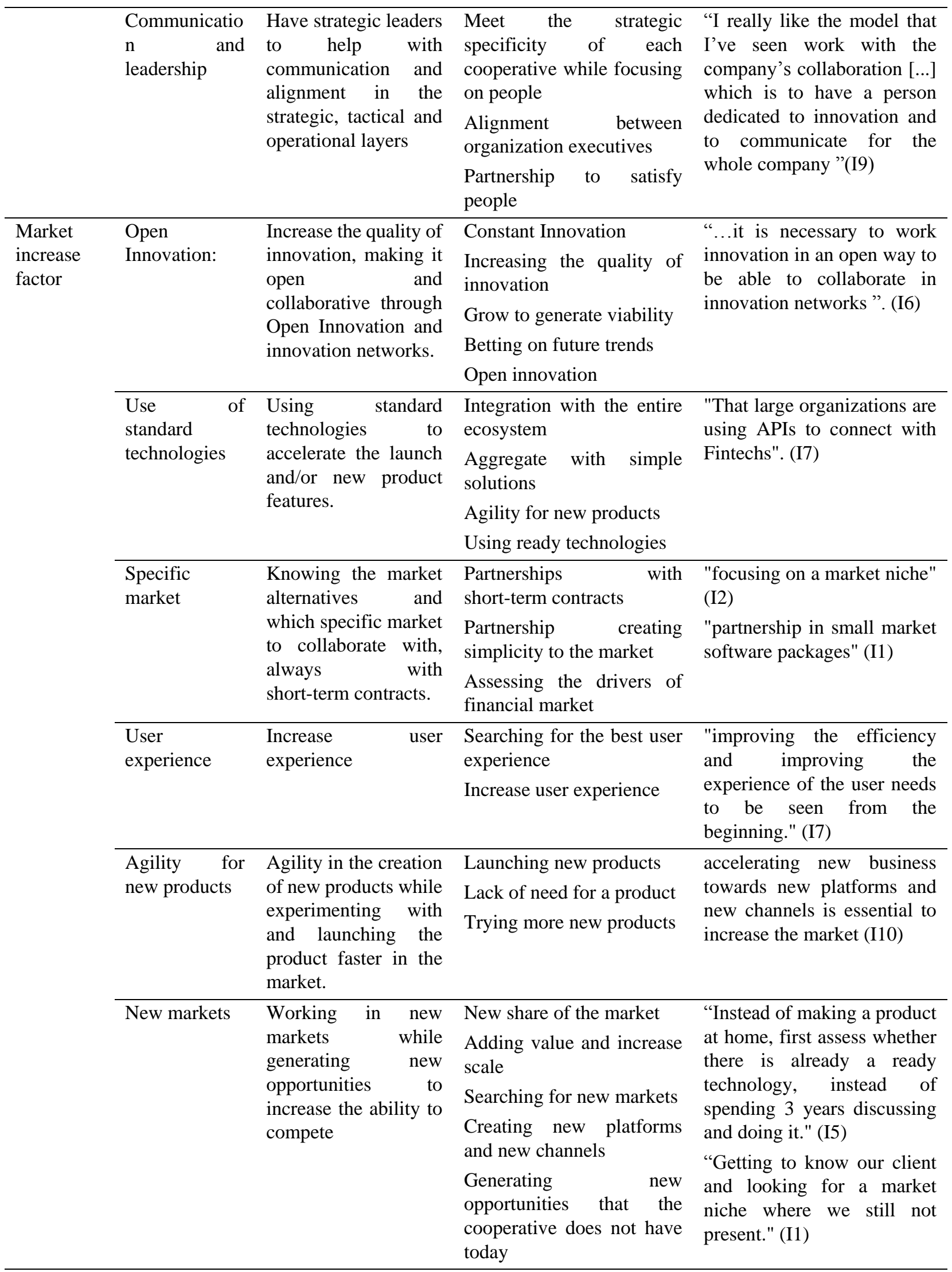




\begin{tabular}{|c|c|c|c|c|}
\hline & $\begin{array}{l}\text { Win-win } \\
\text { collaboration }\end{array}$ & $\begin{array}{l}\text { Adding the results of } \\
\text { the collaboration so } \\
\text { that both win } \\
\text { together. }\end{array}$ & $\begin{array}{l}\text { Having gains on both sides } \\
\text { Adding results to win } \\
\text { together } \\
\text { Win-win partnership }\end{array}$ & $\begin{array}{l}\text { "A good collaboration is } \\
\text { when there is a win-win } \\
\text { partnership" (I2). } \\
\text { "There's got to be the same } \\
\text { understanding of mutual gain } \\
\text { on both sides". (I5) } \\
\text { "Gaining an advantage to get } \\
\text { new customers are gains of } \\
\text { collaboration" (I10) }\end{array}$ \\
\hline & $\begin{array}{l}\text { Trust } \\
\text { facing } \\
\text { market }\end{array}$ & $\begin{array}{l}\text { Filter and classify the } \\
\text { collaboration to } \\
\text { reduce potential } \\
\text { opportunistic risks } \\
\text { and uncertainties, } \\
\text { thus increasing trust } \\
\text { in the market. }\end{array}$ & $\begin{array}{l}\text { Increase of market trust } \\
\text { Assessing whether the } \\
\text { partner company can } \\
\text { comply with the agreement } \\
\text { Certificate from the partner } \\
\text { to the market } \\
\text { Having risk-mitigating } \\
\text { criteria } \\
\text { Assessing the bases of } \\
\text { economic sustainability } \\
\text { Partner reference } \\
\text { Adding more safety }\end{array}$ & $\begin{array}{l}\text { "[...] being careful with } \\
\text { initial ideas; you have to } \\
\text { evaluate the partner by the } \\
\text { size of the risk and not by the } \\
\text { size of the partner" (I7). } \\
\text { "I need a partner with a lot of } \\
\text { ethics, with the same } \\
\text { principles that we have" (I8). } \\
\text { the market needs to be } \\
\text { re-educated, companies do } \\
\text { not trust each other" (I2) }\end{array}$ \\
\hline $\begin{array}{l}\text { Technolog } \\
\text { ical } \\
\text { alignment } \\
\text { factor }\end{array}$ & $\begin{array}{l}\text { Integration } \\
\text { within the } \\
\text { ecosystem }\end{array}$ & $\begin{array}{l}\text { Using ready-made } \\
\text { components, } \\
\text { facilitating } \\
\text { integration } \\
\text { technologies within } \\
\text { the ecosystem. }\end{array}$ & $\begin{array}{l}\text { Integration with the entire } \\
\text { ecosystem } \\
\text { Using ready-made } \\
\text { components } \\
\text { Not using closed standards } \\
\text { Using industry-standard } \\
\text { technological resources } \\
\text { Simplifying and facilitating } \\
\text { ecosystem integrations }\end{array}$ & $\begin{array}{l}\text { "fintechs already have ready } \\
\text { and specific solutions that } \\
\text { treat specific pains." (I6) } \\
\text { "[...] these fintechs are } \\
\text { observing closely and very } \\
\text { concerned with building } \\
\text { solutions that preserve a very } \\
\text { smooth experience for the } \\
\text { customer, always thinking } \\
\text { about the customer and an } \\
\text { easy integration". (I7) }\end{array}$ \\
\hline & $\begin{array}{l}\text { Innovative } \\
\text { Technologies }\end{array}$ & $\begin{array}{l}\text { Using innovative } \\
\text { technologies, always } \\
\text { aiming to be updated } \\
\text { with market trends. }\end{array}$ & $\begin{array}{l}\text { Technological } \\
\text { competitiveness } \\
\text { Using modern applications } \\
\text { Keeping up to date with } \\
\text { new technologies } \\
\text { Using disruptive } \\
\text { technologies }\end{array}$ & $\begin{array}{l}\text { "Innovating is bringing } \\
\text { benefits to the business, } \\
\text { keeping the balance between } \\
\text { innovation and what the } \\
\text { large organization really } \\
\text { needs". (I1) } \\
\text { "...innovative technologies } \\
\text { help speed up IT deliveries to } \\
\text { make cooperatives' lives } \\
\text { easier." (I5) } \\
\text { "... using new technologies } \\
\text { to enable concrete } \\
\text { possibilities to, thus, } \\
\text { leverage the business". (I6) }\end{array}$ \\
\hline
\end{tabular}




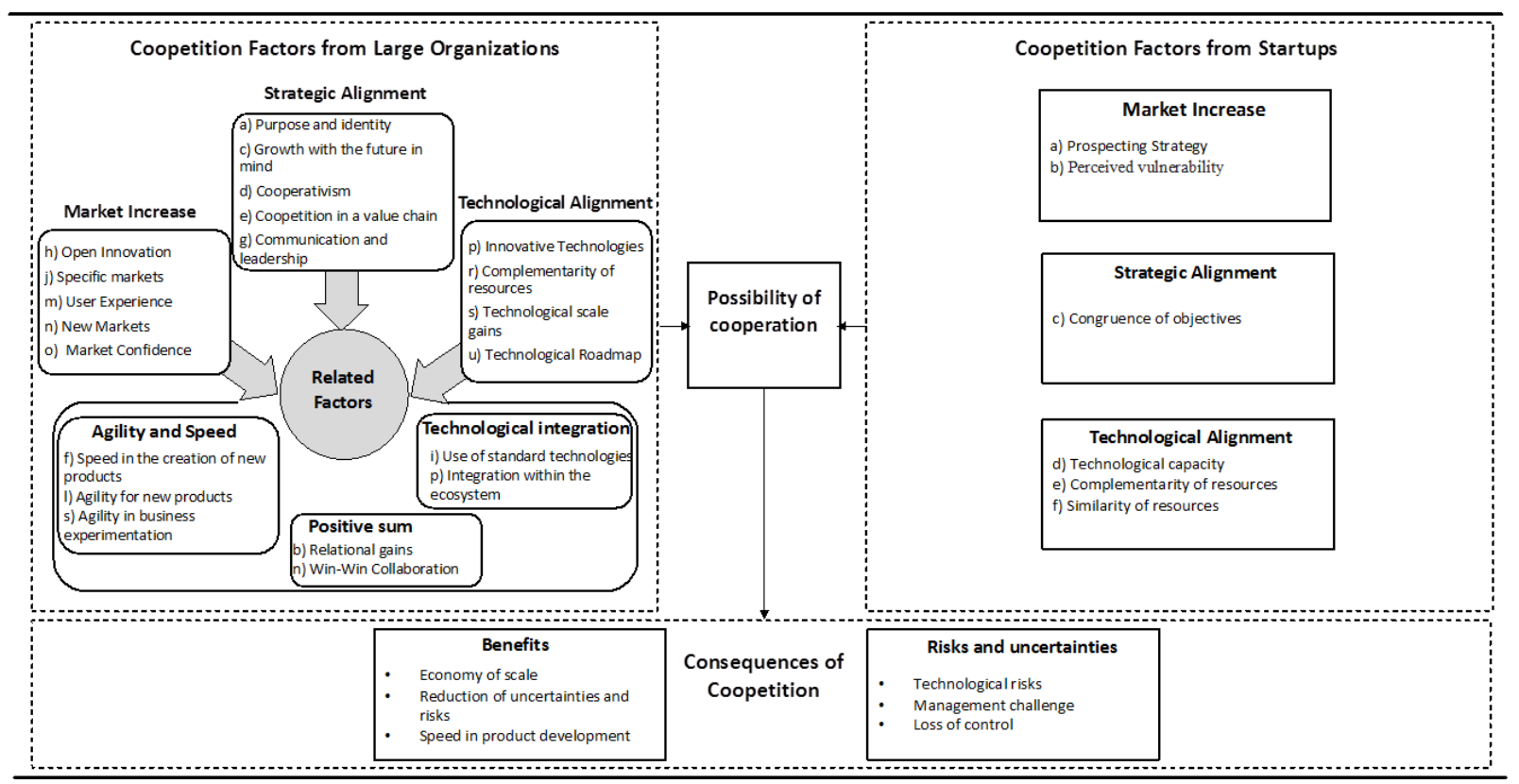

Figure 2. Coopetition Framework between large organizations with Fintechs

The third factor, the technological alignment factor, is made of the characteristics of technological capacity, resource complementarity, and resource similarity. Regarding the technological capacity, the unique skills of a potential partner, such as innovative technology and experience in a given field, are very important factors when selecting partners (Emden et al., 2006). In this sense, large organizations must be aware of how they can add value to startups and vice versa (Weiblen \& Chesbrough, 2015) because it is relevant to combine complementary knowledge and resources to develop new technologies, products, or new market standards (Fonseca \& Meneses, 2020).

Resource complementarity is crucial for the success of coopetition, mainly because of synergies and scale economies (Bleeke \& Ernst, 1991). Partners with complementary resources are less likely to be opportunistic with each other and learn more from the relationship within the ecosystem. Although the rapid convergence of technologies increases organizations' risk and uncertainty, these are reduced when there is cooperation with competitors with complementary resources (Gnyawali \& Park, 2009). At the same time, resource similarity is essential for the search for partners and subsequent organizational learning and knowledge transfer, thus providing a common ground necessary for the potential of technology and to communicate with each other (Emden et al., 2006). On the one hand, large organizations and startups cannot work together if their organizational cultures, management practices, strategic guidelines, and technological systems are very different. On the other hand, similar or complementary strengths of the partners contribute to an increase in the total resources and skills of the alliance, thereby increasing its efficiency (Gnyawali \& Park, 2009). Resource similarity helps to increase scale economies in technological development. As technologies become more complex and sophisticated, they need more resources. However, resource similarity can increase the threat of a partner's opportunistic behavior.

Regarding the phenomena studied, that is, coopetition between large organizations and fintechs, it is relevant to consider three factors: agility and speed; technological integration; and win-win collaboration. Agility and speed focus on the market increasing because of the need to launch and experiment with new products quickly. For their part, fintechs represent the simplicity and agility of the processes while promoting a digital transformation. Moreover, large organizations have shown worry about adapting products and services to customers (Fonseca \& Meneses, 2020). Thus, there is a relevant role in reducing the product launch time to obtain reasonable profits during the short product life cycles (Gnyawali \& Park, 2009).

About the technological integration, our findings showed that this factor is recommended to use industry-standard technology to accelerate the launch of new products or new features. This strategy promotes the agility and speed to faster launch and experimenting with new products while increasing the market share of the adopters. In addition, technological integration allows firms to obtain more heterogeneous knowledge, resulting in more radical products or 
technologies (Chen et al., 2020). Thus, technological integration may be considered in (upstream and downstream) intra-industry relationships between large organizations and fintechs.

Win-win collaborations deal with partners who look for positive-sum games resulting in resources increasing or competences developing (Brandenburger \& Nalebuff, 1996). Our findings showed that a true collaboration may be based on relational gains, that is, with common objectives and mutual gains. However, the gains will not necessarily be shared equally between the parties because it depends on the absorptive capability and the individual power in the relationship strategy (Padula \& Dagnino, 2007). Thus, although coopetition is a paradoxical strategy that presents contradictory logic between competition and cooperation, the relationships between interdependence and resource complementarity result in a positive-sum game (Della Corte, 2018).

\section{Concluding Remarks}

Coopetition is a relevant and complex concept that has emerged as a new theoretical perspective in strategic management. Coopetition can be viewed as a process in which two or more firms cooperate on a joint product or evolve a market while developing unique knowledge, features, or competencies (Chiambaretto et al., 2020). In this sense, our study analyzed the dynamic process of coopetition between an established organization and startups to develop innovation.

Our findings reveal that it is important regarding different factors - market increase, strategic alignment, and technological alignment - that relate to each other. The market increase factor shows the interaction with the markets as a driver to stimulate coopetition strategies. In this sense, we identified that coopetition not only allows developing new markets but also to better understand the users' demands of these markets. The strategic alignment factor is based on the strategic interaction from the coopetition drivers. It focuses on the development of the value chain that allows an appropriation of gains greater than those that could be obtained individually. Finally, the technological alignment factor determines the results of coopetition strategies formulated based on the development of technologies. Thus, coopetition is an accelerator of innovation, allowing the identification of resource complementary and technological scale gains.

Although our study has documented strengths from the GT, it is important to recognize its limitations. First, we consider only 11 respondents. Second, the researchers' experience of the phenomenon was built during the research. Third, our study focused on large organizations and startups from the financial industry. At the same time, our study opens new avenues for future studies that can provide relevant contributions. First, it is important to discuss coopetition in other business models as family businesses and work cooperatives. Second, another possibility is to develop research similar to ours in other financial ecosystems, considering that the Brazilian financial ecosystem is highly regulated and emerging. Third, we also suggest developing similar research in ecosystems other than the financial sector, such as education and health, which are relevant industries and are experiencing different disruptions with the presence of startups in large organizations.

\section{References}

Ahuja, G. (2000). The duality of collaboration: Inducements and opportunities in the formation of interfirm linkages. $\begin{array}{llll}\text { Strategic Management } & \text { Journal, } & \text { 31(3), } & \end{array}$ https://doi.org/10.1002/(SICI)1097-0266(200003)21:3\%3C317::AID-SMJ90\%3E3.0.CO;2-B

Banerjee, S., Riquelme, C., \& Johari, R. (2015). Pricing in ride-share platforms: A queueing-theoretic approach. Working paper. Ithaca, NY: Cornell University. https://doi.org/10.2139/ssrn.2568258

Barney, J. B. (1991). Firm resources and sustained competitive advantage. Journal of Management, 17(1), 99-119. https://doi.org/10.1177/014920639101700108

Barney, J. B. (2001). Resource-based theories of competitive advantage: A ten-year retrospective on the resource-based view. Journal of Management, 27(6), 643-650. https://doi.org/10.1177/014920630102700602

Basterretxea, I., Charterina, J., \& Landeta, J. (2019). Coopetition and innovation. Lessons from worker cooperatives in the Spanish machine tool industry. Journal of Business \& Industrial Marketing, 34(6), 1223-1235. https://doi.org/10.1108/JBIM-01-2018-0015

Bengtsson, M., \& Kock, S. (2014). Coopetition - Quo vadis? Past accomplishments and future challenges. Industrial Marketing Management, 43(2), 180-188. https://doi.org/10.1016/j.indmarman.2014.02.015

Blank, S. (2013). Why the lean start-up changes everything?. Harvard Business Review, 91(5), 63-72. Retrieved from https://hbr.org/2013/05/why-the-lean-start-up-changes-everything 
Blanka, C., \& Traunmüller, V. (2020). Blind date? Intermediaries as matchmakers on the way to start-up-industry coopetition. Industrial Marketing Management, 90, 1-13. https://doi.org/10.1016/j.indmarman.2020.05.031

Bleeke, J., \& Ernst, D. (1991). The way to win in cross-border alliances. Harvard Business Review, 69. Retrieved from https://hbr.org/1991/11/the-way-to-win-in-cross-border-alliances

Bouncken, R. B., Gast, J., Kraus, S., \& Bogers, M. (2015). Coopetition: A systematic review, synthesis, and future research directions. Review of Managerial Science, 9(3), 577-601. https://doi.org/10.1007/s11846-015-0168-6

Brandenburger, A. M., \& Nalebuff, B. J. (1996). Co-opetition. New York: Currency Doubleday.

Charmaz, K. (2006). Constructing Grounded Theory: A practical guide through qualitative analysis. SAGE Publications Ltd.

Chen, H., Yao, Y., Zan, A., \& Carayannis, E. G. (2020). How does coopetition affect radical innovation? The roles of internal knowledge structure and external knowledge integration. Journal of Business \& Industrial Marketing. https://doi.org/10.1108/JBIM-05-2019-0257

Chiambaretto, P., Maurice, J., \& Willinger, M. (2020). Value creation and value appropriation in innovative coopetition projects. Management, 23(2), 61-75. https://doi.org/10.3917/mana.232.0061

Chiao, Y. C., Lin, C. C., \& Huang, C. J. (2020). Competing and cooperating globally: How firms' multimarket contact relates to joint price elevation in coopetition networks. Journal of Business \& Industrial Marketing. https://doi.org/10.1108/JBIM-01-2020-0063

Corbin, J., \& Strauss, A. (2008). Basics of qualitative research: Techniques and procedures for developing Grounded Theory (3rd ed.). Thousand Oaks, CA: SAGE Publications.

Crick, J. M., \& Crick, D. (2020). Coopetition and COVID-19: Collaborative business-to-business marketing strategies in a pandemic crisis. Industrial Marketing Management, 88, 206-213. https://doi.org/10.1016/j.indmarman.2020.05.016

Czakon, W., \& Rogalski, M. (2014). Coopetition typology revisited - a behavioural approach. International Journal of Business Environment, 6(1), 28-46. https://doi.org/10.1504/IJBE.2014.058022

Dahl, J., Kock, S., \& Lundgren-Henriksson, E.-L. (2016). Conceptualizing coopetition strategy as practice: A multilevel interpretative framework. International Studies of Management \& Organization, 46(2-3), 94-109. https://doi.org/10.1080/00208825.2015.1093794

De Carvalho, G. D. G., Cruz, J. A. W., De Carvalho, H. G., Duclós, L. C., \& Corrêa, R. O. (2020). Innovativeness and coopetition in tourism SMEs: comparing two coopetitive networks in Brazil. Journal of Hospitality and Tourism Insights, 3(4), 469-488. https://doi.org/10.1108/JHTI-12-2019-0134

Della Corte, V. (2018). Innovation through coopetition: Future directions and new challenges. Journal of Open Innovation: Technology, Market, and Complexity, 4(4), 47. https://doi.org/10.3390/joitmc4040047

Ejsmont, A. (2017). Cooperation and coopetition as a tools which could improve leading startups all over the world. European Journal of Social Sciences Education and Research Articles, 4(6), 228-237. https://doi.org/10.26417/ejser.v11i2.p228-237

Emden, Z., Calantone, R. J., \& Droge, C. (2006). Collaborating for new product development: Selecting the partner with maximum potential to create value. Journal of Product Innovation Management, 23(4), 330-341. https://doi.org/10.1111/j.1540-5885.2006.00205

Fintech Lab. (2020). Radar Fintechlab. $\quad$ Retrieved from http://fintechlab.com.br/index.php/2020/08/25/edicao-2020-do-radar-fintechlab-detecta-270-novas-fintechs-emum-ano/

Fonseca, C., \& Meneses, R. (2020). Motivations for coopetition strategies between banks and fintechs. Proceedings of the International Conference on Business Excellence, 14(1), 282-293. https://doi.org/10.2478/picbe-2020-0027

Gast, J., Gundolf, K., Harms, R., \& Collado, E. M. (2019). Knowledge management and coopetition: How do cooperating competitors balance the needs to share and protect their knowledge?. Industrial Marketing Management, 77, 65-74. https://doi.org/10.1016/j.indmarman.2018.12.007

Glaser, G. B. (1998). Doing Grounded Theory: Issues and discussions. Mill Valley, CA: The Sociology Press. 
Gnyawali, D. R., \& Park, B. J. (2009). Co-opetition and technological innovation in small and medium-sized enterprises: A multilevel conceptual model. Journal of Small Business Management, 47(3), 308-330. https://doi.org/10.1111/j.1540-627X.2009.00273.X

Granata, J., Lasch, F., Le Roy, F., \& Dana, L.-P. (2018). How do micro-firms manage coopetition? A study of the wine sector in France. International Small Business Journal: Researching Entrepreneurship, 36(3), 331-355. https://doi.org/10.1177\%2F0266242617740412

Hamel, G., Doz, Y., \& Prahalad, C. K. (1989). Collaborate with your competitors-and win. Harvard Business Review, 67(1), 133-139. Retrieved from https://hbr.org/1989/01/collaborate-with-your-competitors-and-win

Hannah, D. P., \& Eisenhardt, K. M. (2018). How firms navigate cooperation and competition in nascent ecosystems. Strategic Management Journal, 39(12), 3163-3192. https://doi.org/10.1002/smj.2750

Hitt, M. A., Ireland, R. D., \& Hoskisson, R. E. (2007). Strategic management: Competitiveness and globalization (7th ed.). Thomson Higher Education.

Hoffmann, W., Lavie, D., Reuer, J. J., \& Shipilov, A. (2018). The interplay of competition and cooperation. Strategic Management Journal, 39(12), 3033-3052. https://doi.org/10.1002/smj.2965

Holotiuk, F., Klus, M. F., Lohwasser, T. S., \& Moormann, J. (2018). Motives to form alliances for digital innovation: The case of banks and Fintechs. BLED 2018 Proceedings, 22, 301-316. Retrieved from htps://aisel.aisnet.org/bled2018/22

Hora, W., Gast, J., Kailer, N., Rey-Marti, A., \& Mas-Tur, A. (2018). David and Goliath: Causes and effects of coopetition between start-ups and corporates. Review of Managerial Science, 12(2), 411-439. https://doi.org/10.1007/s11846-017-0273-9

Krommendijk, J. (2016). Between pretence and practice: The Dutch response to recommendations of International Human Rights Bodies. In M. Heijer, \& H. Van Der Wilt (Eds.), Netherlands Yearbook of International Law 2015 (Vol. 46, pp. 421-438). T.M.C. Asser Press, The Hague. https://doi.org/10.1007/978-94-6265-114-2_15

Lacam, J. S., \& Salvetat, D. (2017). The complexity of co-opetitive networks. Business Process Management Journal, 23(1), 176-195. https://doi.org/10.1108/BPMJ-12-2015-0187

Lado, A. A., Boyd, N. G., \& Hanlon, S. C. (1997). Competition, cooperation, and the search for economic rents: A syncretic model. Academy of Management Review, 22(1), 110-141. https://doi.org/10.2307/259226

Lado, A. A., Boyd, N. G., \& Wright, P. (1992). A competency-based model of sustainable competitive advantage: Toward a conceptual integration. Journal of Management, 18, 77-91. https://doi.org/10.1177/014920639201800106

Lechner, C., Dowling, M., \& Welpe, I. (2006). Firm networks and firm development: The role of the relational mix. Strategic Management Journal, 21(4), 514-540. https://doi.org/10.1016/j.jbusvent.2005.02.004

Lee, I., \& Shin, Y. J. (2018). Fintech: Ecosystem, business models, investment decisions, and challenges. Business Horizons, 61(1), 35-46. https://doi.org/10.1016/j.bushor.2017.09.003

Lincoln, N. D. Y., \& Guba, E. (1995). Handbook of qualitative research methods. Thousand Oaks, CA: Sage.

Mattsson, L. G., \& Tidström, A. (2015). Applying the principles of Yin-Yang to market dynamics: On the duality of cooperation and competition. Marketing Theory, 15(3), 347-364. https://doi.org/10.1177\%2F1470593114564903

McCarthy, C., Carleton, P., Krumpholz, E., \& Chow, M. (2018). Accelerating innovation through coopetition: The innovation learning network experience. Nursing Administration Quarterly, 42(1), 26-34. https://doi.org/10.1097/NAQ.0000000000000268

Minà, A., Dagnino, G. B., \& Vagnani, G. (2020). An interpretive framework of the interplay of competition and cooperation. Journal of Management and Governance, 24(1), 1-35. https://doi.org/10.1007/s10997-019-09498-6

Nakanishi, Y. (2020). Interplay between coopetition and institutions: How Japanese airlines enhance bargaining power. $\begin{array}{lllll}\text { Journal of Co-operative Organization and Management, } & 8(2), & 100120 .\end{array}$ https://doi.org/10.1016/j.jcom.2020.100120

Nonaka, I., Kodama, M., Hirose, A., \& Kohlbacher, F. (2014). Dynamic fractal organizations for promoting knowledge-based transformation - A new paradigm for organizational theory. European Management Journal, 32(1), 137-146. https://doi.org/10.1016/j.emj.2013.02.003 
Nowell, L. S., Norris, J. M., White, D. E., \& Moules, N. J. (2017). Thematic analysis: Striving to meet the trustworthiness criteria. International Journal of Qualitative Methods, 16(1), 1-13. https://doi.org/10.1177/1609406917733847

Nutter, G. W., \& Moore, J. H. (1976). A theory of competition. Journal of Law and Economics, 19(1), 39-65. https://doi.org/10.1086/466855

Padula, G., \& Dagnino, G. B. (2007). Untangling the rise of coopetition: The intrusion of competition in a cooperative game structure. International Studies of Management \& Organization, 37(2), 32-52. https://doi.org/10.2753/IMO0020-8825370202

Peng, T. A., Yen, M. H., \& Bourne, M. (2018). How rival partners compete based on cooperation?. Long Range Planning, 51(2), 351-383. https://doi.org/10.1016/j.1rp.2017.10.003

Powell, W. W. (1990). Neither market, nor hierarchy: Network forms of organization. Research in Organizational Behavior, 12, 295-336. Retrieved from http://www.uvm.edu/pdodds/files/papers/others/1990/powell1990a.pdf

PwC. (2018). Brasil fintech deep dive 2018. Retrieved from https://www.pwc.com.br/pt/setores-de-atividade/financeiro/2018/fintech_deep_dive_ingles_18.pdf

Quintana-García, C., \& Benavides-Velasco, C. A. (2004). Cooperation, competition and innovative capability: A panel data of European dedicated biotechnology firms. Technovation, 24(12), 927-938. https://doi.org/10.1016/S0166-4972(03)00060-9

Raza-Ullah, T., Bengtsson, M., \& Kock, S. (2014). The coopetition paradox and tension in coopetition at multiple levels. Industrial Marketing Management, 43(2), 189-198. https://doi.org/10.1016/j.indmarman.2013.11.001

Ritala, P., Kraus, S., \& Bouncken, R. B. (2016). Introduction to coopetition and innovation: Contemporary topics and future research opportunities. International Journal of Technology Management, 71(1-2), 1-9. https://doi.org/10.1504/IJTM.2016.077985

Rusko, R. (2014). Mapping the perspectives of coopetition and technology-based strategic networks: A case of $\begin{array}{llll}\text { smartphones. Industrial } & \text { Marketing }\end{array}$ https://doi.org/10.1016/j.indmarman.2014.04.013

Salkowitz, R. (2013). How startups are reinventing marketing from the bottom up. Retrieved from https://www.slideshare.net/Microsoft/reinventing-marketing-from-the-bottom-up

Sarkar, M., Echambadi, R., Cavusgil, S. T., \& Aulakh, P. S. (2001). The influence of complementarity, compatibility, and relationship capital on alliance performance. Journal of the Academy of Marketing Science, 29(4), 358. https://doi.org/10.1177/03079450094216

Shijaku, E., \& Ritala, P. (2020). Antecedents of coopetition network dynamics performance feedback and network embeddedness. Academy of Management Proceedings, $2020(1), \quad 14934$. https://doi.org/10.5465/AMBPP.2020.14934abstract

Strauss, J., \& Corbin, A. (1998). Basics of qualitative research: Techniques and procedures for Developing Grounded Theory. Thousand Oaks, CA: SAGE Publications.

Suddaby, R. (2006). From the Editors: What Grounded Theory is not. Academy of Management Journal, 49(4). https://doi.org/10.5465/AMJ.2006.22083020

Tidström, A., \& Rajala, A. (2016). Coopetition strategy as interrelated praxis and practices on multiple levels. Industrial Marketing Management, 58, 35-44. https://doi.org/10.1016/j.indmarman.2016.05.013

Van Alstyne, M. W., Parker, G. G., \& Choudary, S. P. (2016). Pipelines, platforms, and the new rules of strategy. Harvard Business Review, 94(4), 54-60. Retrieved from https://hbr.org/2016/04/pipelines-platforms-and-the-new-rules-of-strategy

Verschoore, J. R., \& Adami, V. S. (2020). Interplay of competition and cooperation in wind farm interorganizational projects: Relational approach. Journal of Management in Engineering, 36(1), 04019034. https://doi.org/10.1061/(ASCE)ME.1943-5479.0000723

Weiblen, T., \& Chesbrough, H. (2015). Engaging with startups to enhance corporate innovation. California Management Review, 57(2), 66-90. https://doi.org/10.1525/cmr.2015.57.2.66

Wilhelm, M., \& Sydow, J. (2018). Managing coopetition in supplier networks-a paradox perspective. Journal of Supply Chain Management, 54(3), 22-41. https://doi.org/10.1111/jscm.12167 
Wilkinson, I., \& Young, L. (2002). On cooperating: Firms, relations and networks. Journal of Business Research, 55(2), 123-132. https://doi.org/10.1016/S0148-2963(00)00147-8

Williamson, O. E. (1985). The economic institutions of capitalism. New York, NY: The Free Press.

\section{Copyrights}

Copyright for this article is retained by the author(s), with first publication rights granted to the journal.

This is an open-access article distributed under the terms and conditions of the Creative Commons Attribution license (http://creativecommons.org/licenses/by/4.0/). 